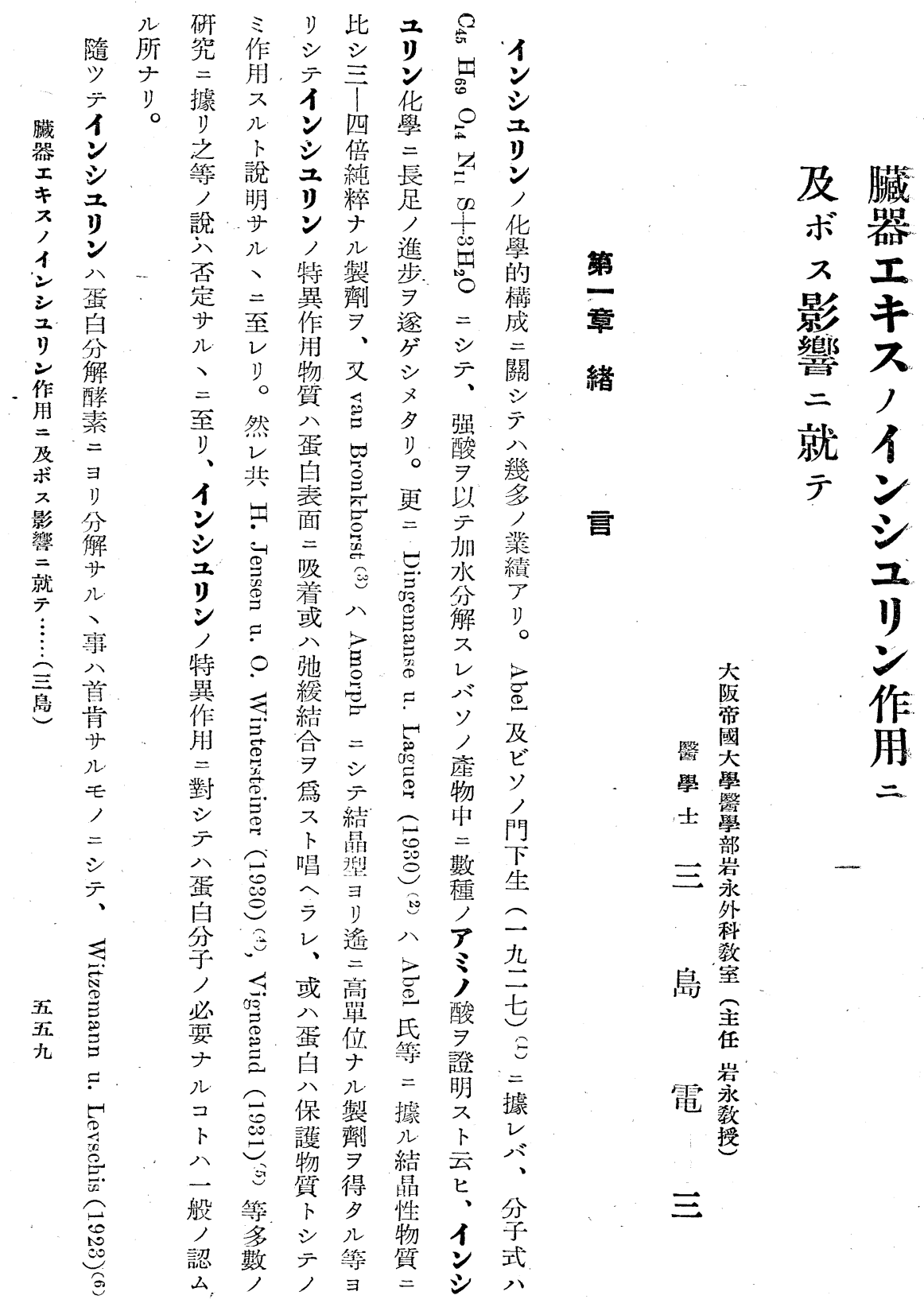




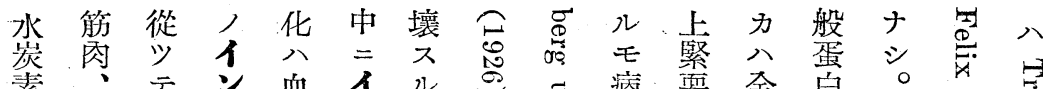
素腎

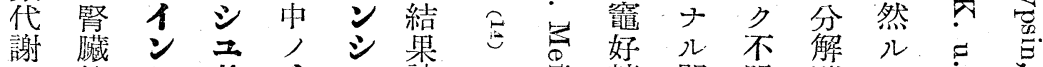
二等 シ 對ノ

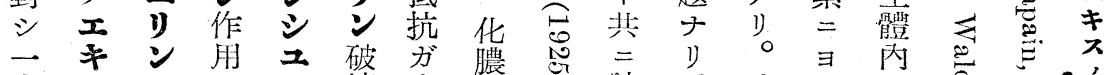

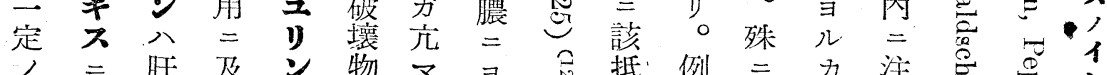

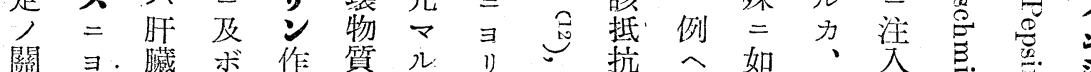
係り

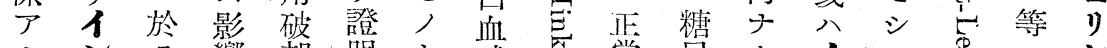

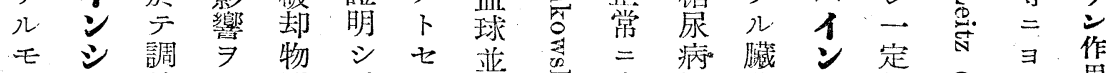

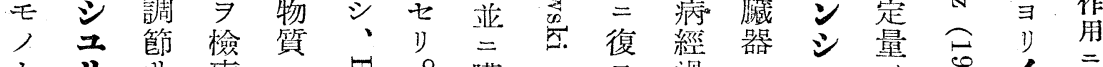

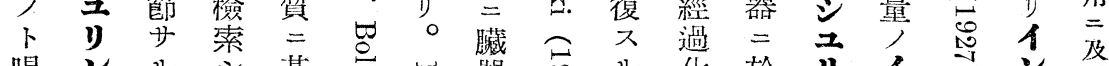

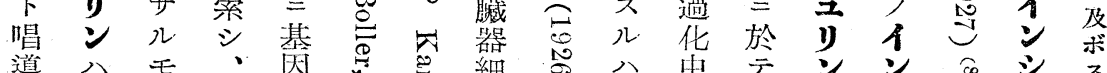

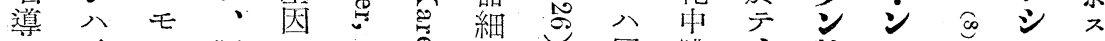

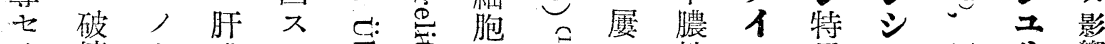
リ塆 上 臟 ル

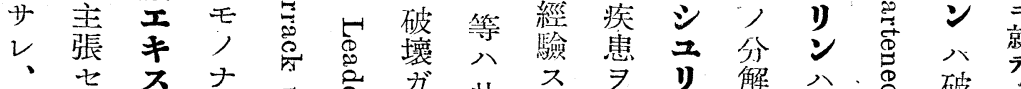

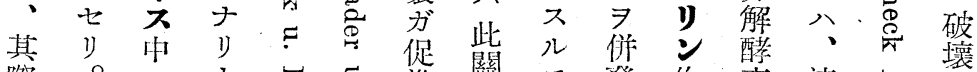

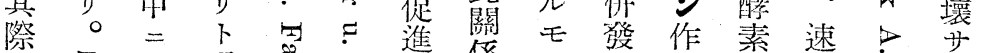
圱最 分 分 解

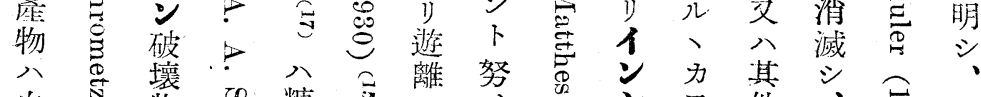
血 壳 物 物 糖

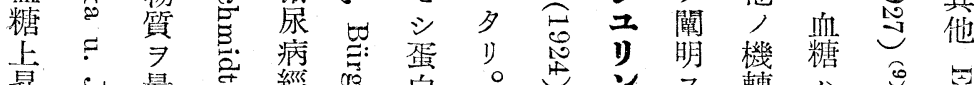
作功它過分等

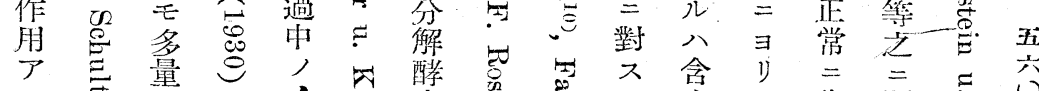

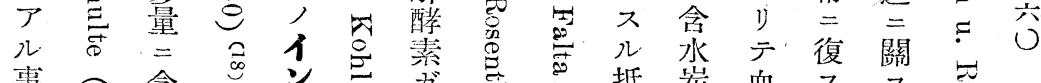
事 点有公

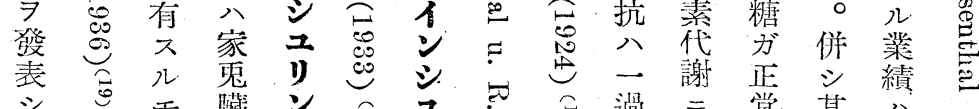

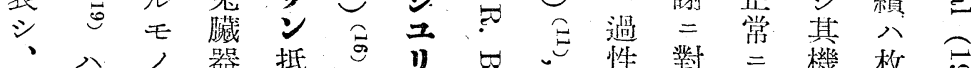

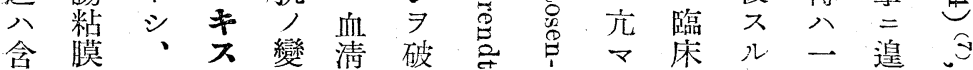



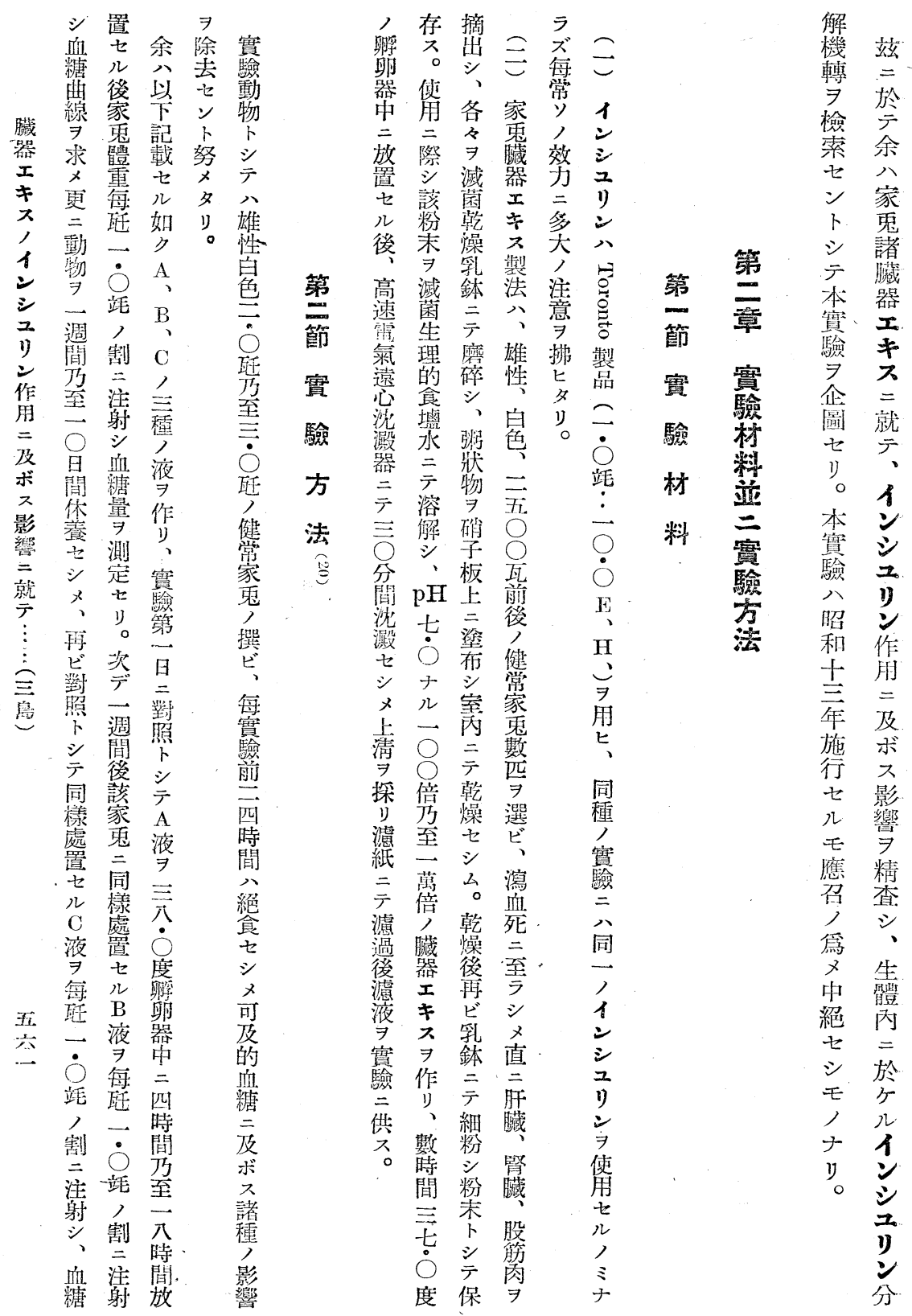


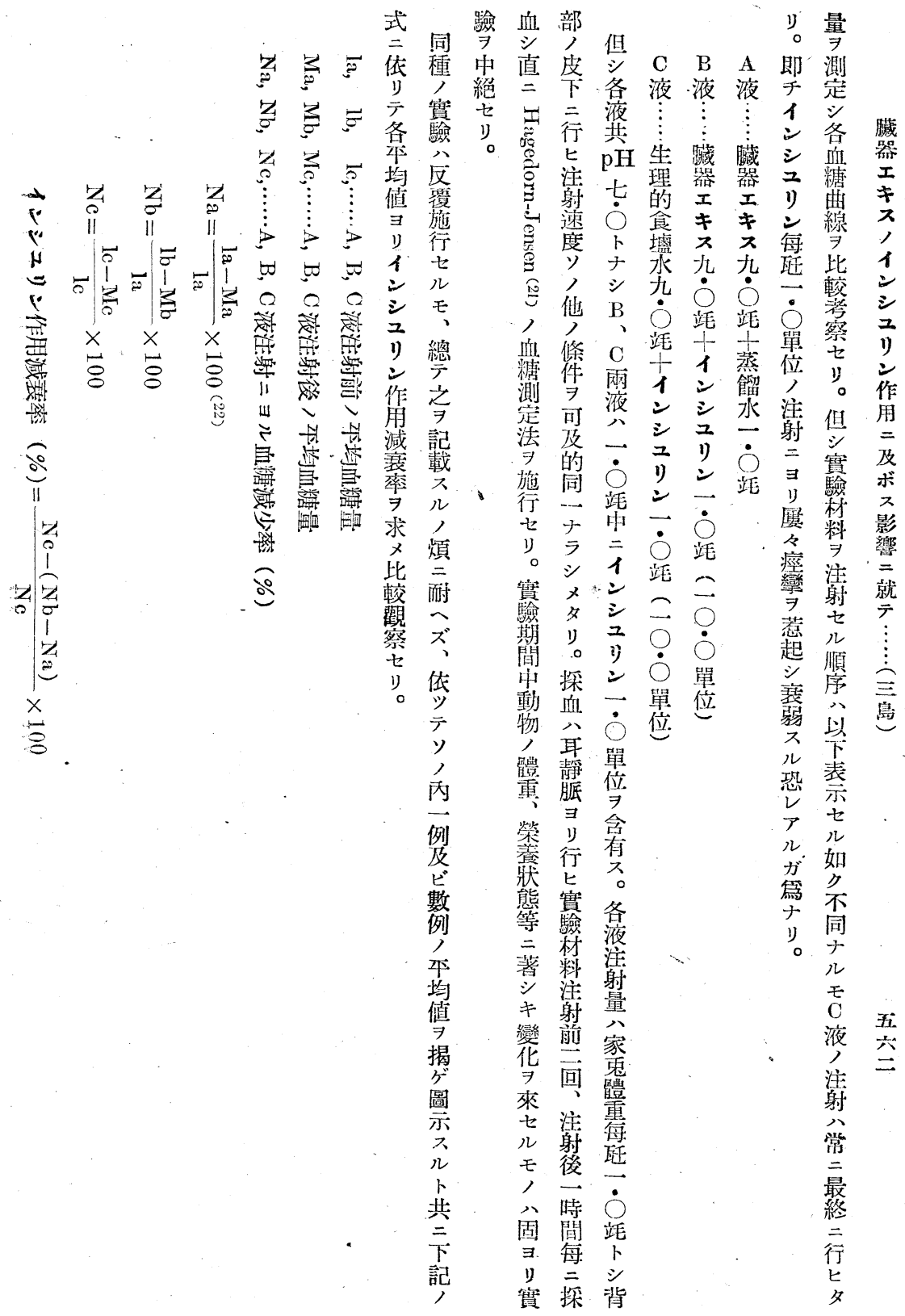




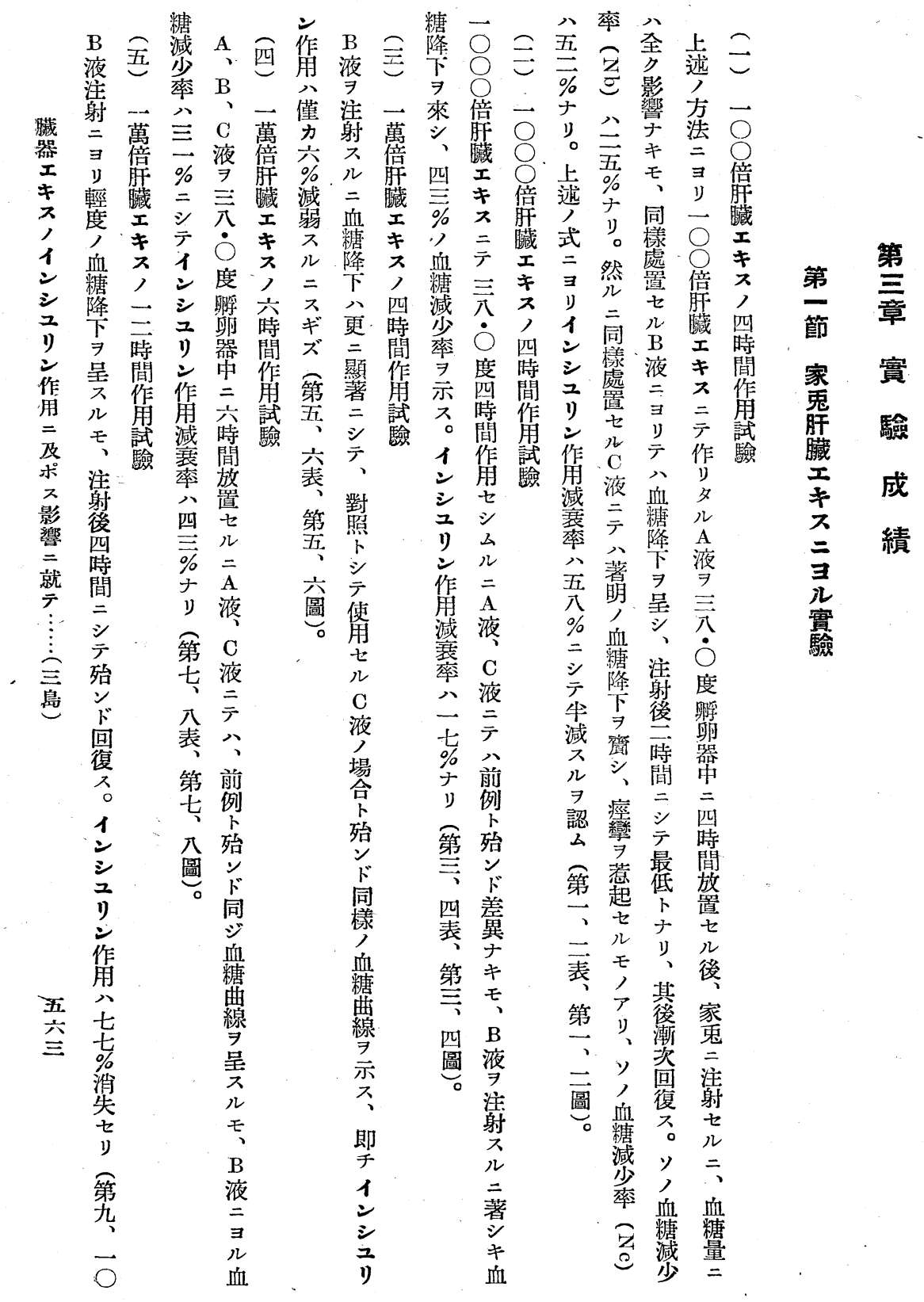


第一表 100 倍肝臟エキス: 4 時間作用

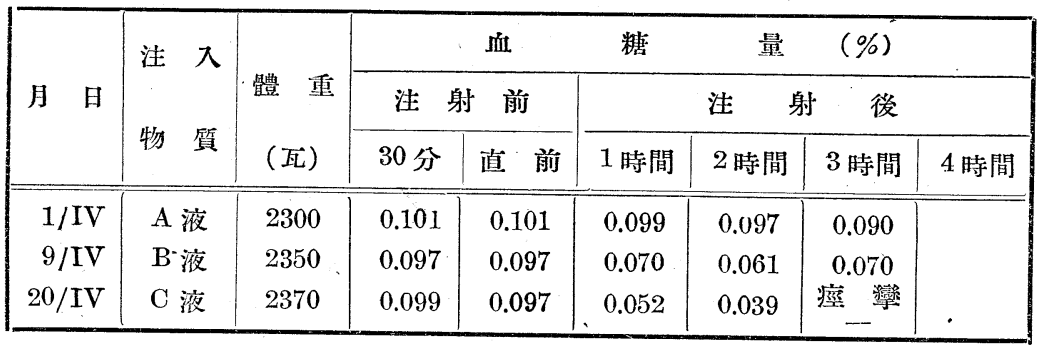

第二表 100 倍肝蹒藏エキス: 4 時間作用（本均値）

\begin{tabular}{|c|c|c|c|c|c|c|c|}
\hline \multirow{3}{*}{$\begin{array}{l}\text { 注 } \\
\text { 物 質 }\end{array}$} & \multicolumn{2}{|r|}{ 血 } & 糖 & 量 & \multicolumn{2}{|l|}{$(\%)$} & \multirow{3}{*}{$\begin{array}{l}\text { 血糖量 } \\
\text { 减少菜 }\end{array}$} \\
\hline & \multicolumn{2}{|c|}{ 注 射 前 } & \multicolumn{2}{|c|}{ 注 } & \multicolumn{2}{|c|}{ 後 } & \\
\hline & 30 分 & 直 前 & 1 時間 & 2 時間 & 3 時間 & 4 時間 & \\
\hline A 液 & 0.101 & 0.102 & 0.098 & 0.099 & 0.099 & & $3 \%$ \\
\hline B 液 & 0.101 & 0.102 & 0.078 & 0.072 & 0.077 & & $25 \%$ \\
\hline $\mathrm{C}$ 液 & 0.101 & 0.101 & 0.059 & 0.043 & 0.042 & & $52 \%$ \\
\hline
\end{tabular}

インシュリン作用減衰渠 $58 \%$

第 一 圖

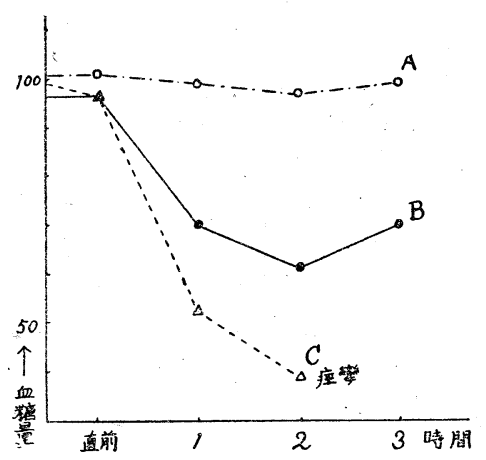

第 = 圖 (本均値)

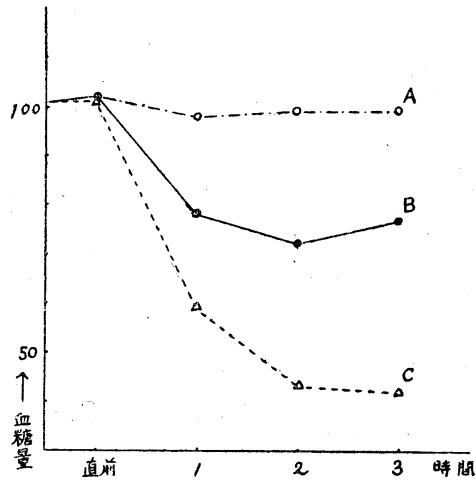

五

究
A …... 100 倍肝臟エキス十蒸䬫水

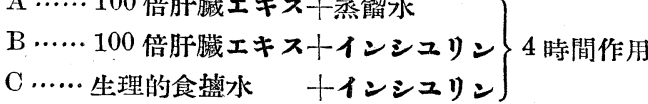


第三表 1000 倍肝臟エキス : 4 時間作用

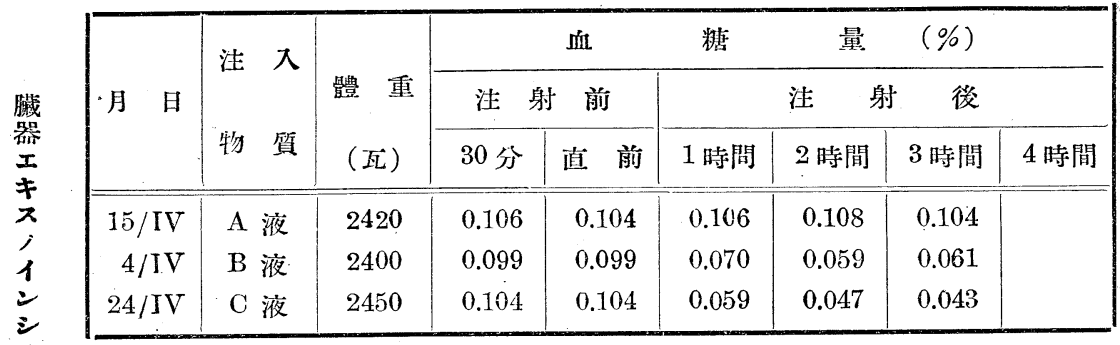

第四表 1000 倍肝臟エキス: 4 時間作用（本均值）

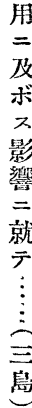

\begin{tabular}{|c|c|c|c|c|c|c|c|}
\hline \multirow{3}{*}{$\begin{array}{l}\text { 注 入 } \\
\text { 物 質 }\end{array}$} & \multicolumn{3}{|c|}{ 血 } & 量 & \multicolumn{2}{|l|}{$(\%)$} & \multirow{3}{*}{$\begin{array}{l}\text { 血糖量 } \\
\text { 減少率 }\end{array}$} \\
\hline & \multicolumn{2}{|c|}{ 注 射 前 } & \multicolumn{2}{|c|}{ 注 } & \multicolumn{2}{|c|}{ 後 } & \\
\hline & 30 分 & 直 前 & 1 時間 & 2 時閣 & 3 時間 & 4 時間 & \\
\hline$A$ 液 & 0.099 & 0.099 & 0.101 & 0.101 & 0.099 & & $-1 \%$ \\
\hline B 液 & 0.097 & 0.098 & 0.066 & 0.051 & 0.052 & & $43 \%$ \\
\hline $\mathrm{C}$ 液 & 0.102 & 0.101 & 0.056 & 0.045 & 0.043 & & $53 \%$ \\
\hline
\end{tabular}

インシュリン作用減衰涼 $17 \%$

第四圖（平均值）

第三圆
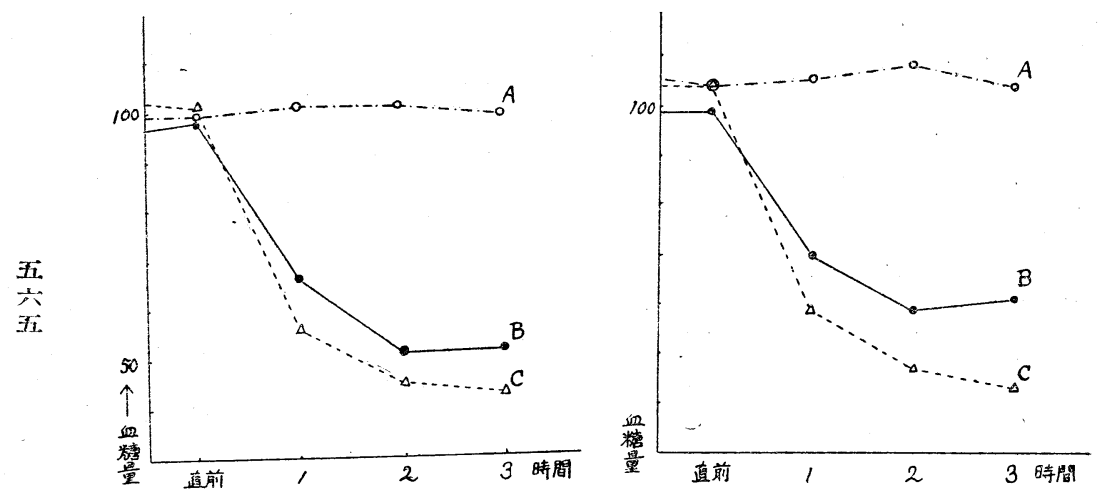

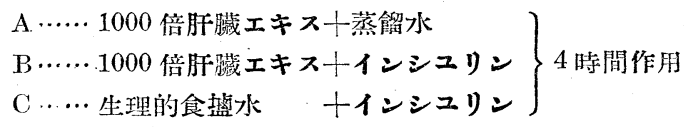


第五表 1 萬倍肝臟エキス: 4 時間作用

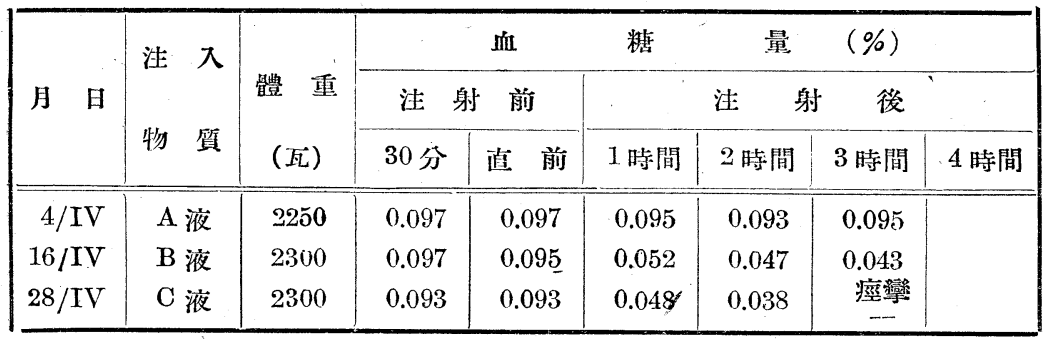

第衣衰 1 萬倍肝臟エキス: 4 時間作用 (本均値)

\begin{tabular}{|c|c|c|c|c|c|c|c|}
\hline \multirow{3}{*}{$\begin{array}{l}\text { 注 入 } \\
\text { 物 質 }\end{array}$} & \multicolumn{2}{|r|}{ 血 } & 糖 & 量 & \multicolumn{2}{|l|}{$\%)$} & \multirow{3}{*}{$\begin{array}{c}\text { 血楉量 } \\
\text { 娍少窑 }\end{array}$} \\
\hline & \multicolumn{2}{|c|}{ 注 射 前 } & \multicolumn{2}{|c|}{ 注 } & \multicolumn{2}{|c|}{ 後 } & \\
\hline & 30 分 & 㨁 前 & 1 時閒 & 2 特間 & 3 時間 & 4 時間 & \\
\hline A 液 & 0.104 & 0.103 & 0.103 & 0.103 & 0.104 & & $1 \%$ \\
\hline $\mathrm{B}$ 液 & 0.106 & 0.106 & 0.065 & 0.049 & 0.043 & & $51 \%$ \\
\hline $\mathrm{C}$ 液 & 0.102 & 0.101 & 0.059 & 0.044 & 0.041 & & $53 \%$ \\
\hline
\end{tabular}

インシュリン作用減衰邎 $6 \%$

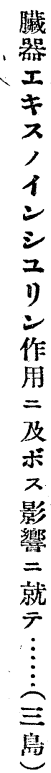
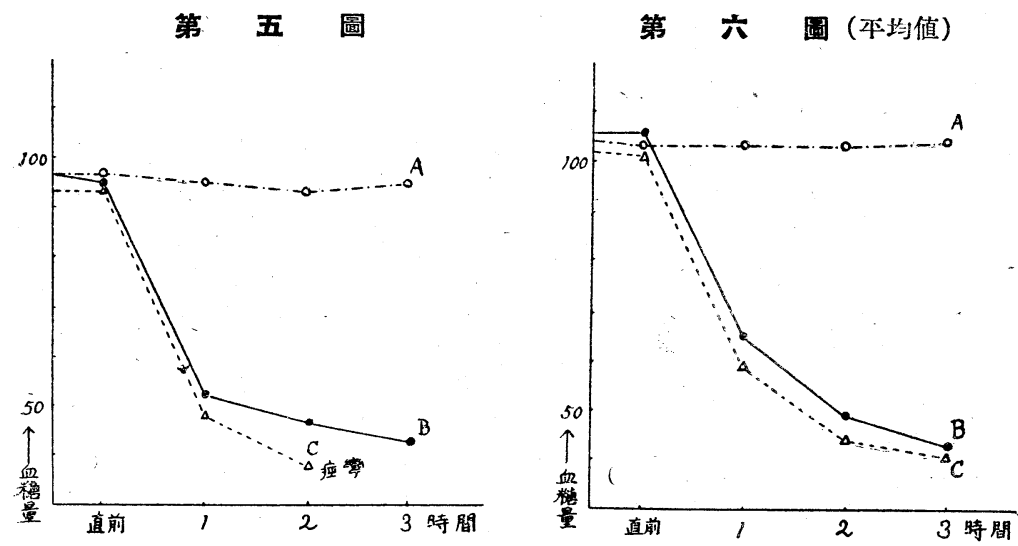

吾
A …...10,000倍肝臟エキス十蒸馏水
B ……10,000倍肝臟エキストイシシュリン $\} 4$ 時間作用

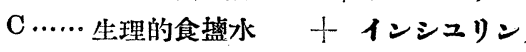


第七表 1 萬倍肝臟エキス: 6 時間作用

\begin{tabular}{|c|c|c|c|c|c|c|c|c|}
\hline \multirow{3}{*}{ 月 日 } & \multirow{3}{*}{$\begin{array}{l}\text { 注 } \\
\text { 物 質 }\end{array}$} & \multirow{3}{*}{$\begin{array}{l}\text { 體 重 } \\
\text { （瓦） }\end{array}$} & \multicolumn{3}{|c|}{ 血 } & \multicolumn{3}{|c|}{$(\%)$} \\
\hline & & & 注 & 前 & & 注 & 後 & \\
\hline & & & 30 分 & 直 前 & 1 時間 & 2 時間 & 3 時間 & 4 時間 \\
\hline $6 / \mathrm{V}$ & $\mathbf{A}$ 液 & 2270 & 0.102 & 0.102 & 0.101 & 0.101 & 0.099 & 0.099 \\
\hline $14 / \mathrm{V}$ & $\mathrm{B}$ 液 & 2250 & 0.093 & 0.093 & 0.059 & 0.057 & 0.065 & 0.077 \\
\hline $26 / \mathrm{V}$ & C 液 & 2280 & 0.097 & 0.099 & 0.056 & 0.043 & 0.039 & 0.041 \\
\hline
\end{tabular}

第八表 1 萬倍肝臟エキス: 6 時間作用，平均值

\begin{tabular}{|c|c|c|c|c|c|c|c|c|}
\hline & & 血. & 糖 & 量 & $\%)$ & & \multirow{3}{*}{\multicolumn{2}{|c|}{$\begin{array}{l}\text { 血 䅯 量 } \\
\text { 減 少 率 }\end{array}$}} \\
\hline & \multicolumn{2}{|c|}{ 注 射 前 } & \multicolumn{2}{|c|}{ 注 } & \multicolumn{2}{|c|}{ 後 } & & \\
\hline & 30 分 & 直 前 & 1 時間 & 2 時間 & 3 時間 & 4 時間 & & \\
\hline A 液 & 0.099 & 0.099 & 0.096 & 0.098 & 0.099 & 0.099 & $1 \%$ & \\
\hline $\mathrm{B}$ 液 & 0.103 & 0.104 & 0.068 & 0.066 & 0.071 & 0.082 & $31 \%$ & \\
\hline $\mathrm{C}$ 液 & 0.101 & 0.099 & 0.056 & 0.044 & 0.040 & 0.048 & $53 \%$ & \\
\hline
\end{tabular}

インシュリン作用減衰率 $43 \%$

蒡 七圖

五
六
七

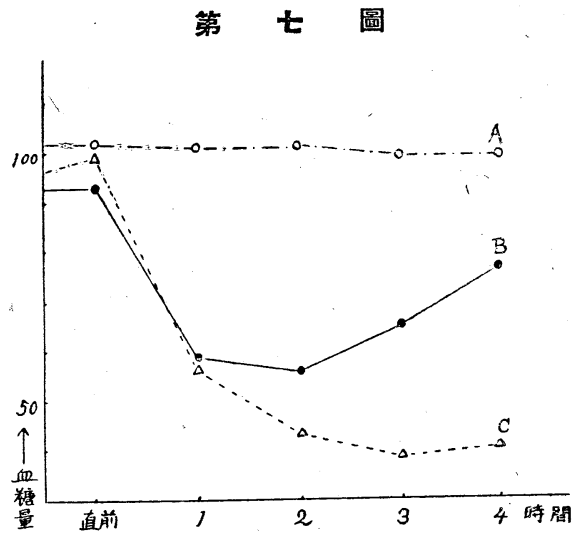




\section{第八 圖 (本均值)}

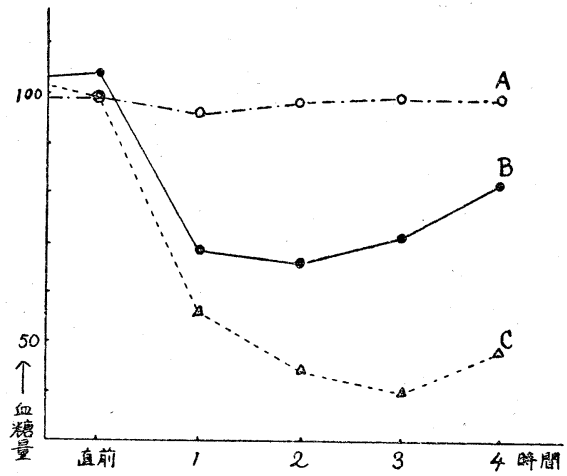

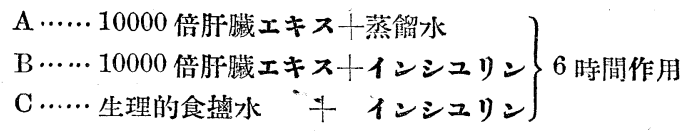

第九表 1 萬倍肝臟エキス: 12 時間作用

\begin{tabular}{|c|c|c|c|c|c|c|c|c|c|}
\hline \multirow{3}{*}{ 月 } & \multirow{3}{*}{\multicolumn{2}{|c|}{$\begin{array}{l}\text { 注 } \\
\text { 物 質 }\end{array}$}} & \multirow{3}{*}{$\begin{array}{c}\text { 體 重 } \\
\text { (瓦) }\end{array}$} & \multicolumn{6}{|c|}{ 量 $\quad(\%)$} \\
\hline & & & & \multicolumn{2}{|c|}{ 注 射 前 } & \multicolumn{2}{|c|}{ 注 } & \multicolumn{2}{|c|}{ 後 } \\
\hline & & & & 30 分 & 直 前 & 1 時間 & 2 時間 & 3 時間 & 4 時間 \\
\hline $19 / \mathrm{V}$ & A & 液 & 2050 & 0.097 & 0.095 & 0.095 & 0.093 & 0.097 & 0.097 \\
\hline $27 / \mathrm{V}$ & B & 液 & 2080 & 0.099 & 0.097 & 0.084 & 0.086 & 0.084 & 0.095 \\
\hline $4 / \mathrm{VI}$ & $\mathrm{C}$ & 液 & 2100 & 0.101 & 0.101 & 0.057 & 0.045 & 0.041 & 0.043 \\
\hline
\end{tabular}

第十表 1 萬倍肝臟エキス：12 時間作用 平均值

\begin{tabular}{|c|c|c|c|c|c|c|c|c|}
\hline \multirow{3}{*}{$\begin{array}{l}\text { 注 } \\
\text { 物 筫 }\end{array}$} & & 血 & 糖 & & & & \multirow{3}{*}{\multicolumn{2}{|c|}{$\begin{array}{l}\text { 血 糖 量 } \\
\text { 減 少 率 }\end{array}$}} \\
\hline & \multicolumn{2}{|c|}{ 洼 射 前 } & \multicolumn{2}{|c|}{ 注 } & \multicolumn{2}{|c|}{ 後 } & & \\
\hline & 30 分 & 直 前 & 1 時間 & 2 時間 & 3 時間 & 4 時間 & & \\
\hline A 液 & 0.099 & 0.098 & 0.097 & 0.099 & 0.098 & 0.099 & $1 \%$ & \\
\hline$B$ 液 & 0.103 & 0.104 & 0.088 & 0.088 & 0.090 & 0.096 & $13 \%$ & \\
\hline C 液 & 0.102 & 0.103 & 0.058 & 0.045 & 0.042 & 0.048 & $53 \%$ & \\
\hline
\end{tabular}



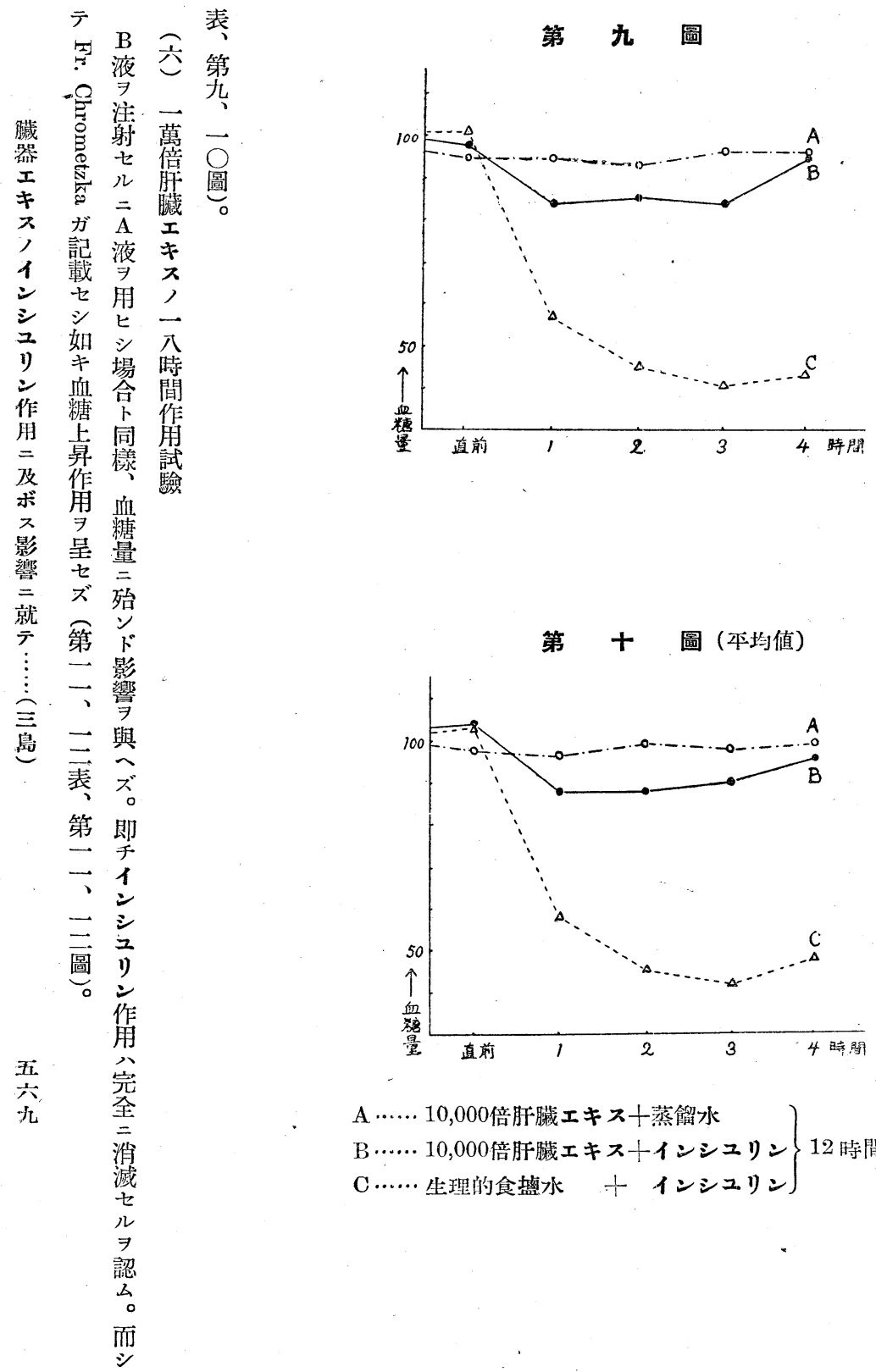

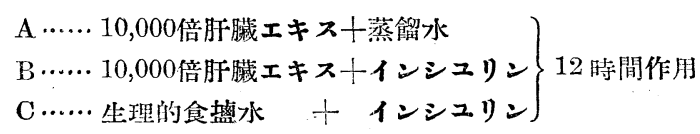


第十一表 1 萬倍肝藏エキス: 18 時間作用

\begin{tabular}{|c|c|c|c|c|c|c|c|c|c|}
\hline \multirow{3}{*}{ 月 日 } & \multirow{3}{*}{\multicolumn{2}{|c|}{$\begin{array}{l}\text { 注 入 } \\
\text { 物 質 }\end{array}$}} & \multirow{3}{*}{$\begin{array}{c}\text { 體 重 } \\
\text { （瓦） }\end{array}$} & \multicolumn{2}{|r|}{ 血 } & \multicolumn{4}{|c|}{ 量 $(\%)$} \\
\hline & & & & \multicolumn{2}{|c|}{ 注 射 前 } & \multicolumn{2}{|c|}{ 注 } & \multicolumn{2}{|c|}{ 後 } \\
\hline & & & & 30 分 & 直 前 & 1 時間 & 2 時間 & 3 時間 & 4 時間 \\
\hline $6 / \mathrm{V}$ & A & 液 & 2000 & 0.086 & 0.088 & 0.086 & 0.083 & 0.084 & 0.084 \\
\hline $15 / \mathrm{V}$ & B & 液 & 2000 & 0.088 & 0.090 & 0.088 & 0.090 & 0.090 & 0.088 \\
\hline $25 / \mathrm{V}$ & C & 液 & 2050 & 0.092 & 0.092 & 0.052 & 0.041 & 痤 & 挙 \\
\hline
\end{tabular}

第十二表 1 萬倍肝枵藏エキス：18時間作用 平均値

\begin{tabular}{|c|c|c|c|c|c|c|c|c|}
\hline \multirow{3}{*}{\multicolumn{2}{|c|}{$\begin{array}{ll}\text { 注 } & \text { 入 } \\
\text { 物 質 }\end{array}$}} & \multicolumn{6}{|c|}{ 血 糖 量 $(\%)$} & \multirow{3}{*}{$\begin{array}{l}\text { 血 糖 量 } \\
\text { 減 少 率 }\end{array}$} \\
\hline & & \multicolumn{2}{|c|}{ 注 射 前 } & \multicolumn{2}{|c|}{ 注 } & \multicolumn{2}{|c|}{ 的 後 } & \\
\hline & & 30 分 & 直 前 & 1 時間 & 2 時間 & 3 洔閒 & 4 時閒 & \\
\hline A & 液 & 0.102 & 0.101 & 0.101 & 0.101 & 0.099 & 0.101 & $1 \%$ \\
\hline B & 液 & 0.098 & 0.098 & 0.099 & 0.097 & 0.099 & 0.098 & $0 \%$ \\
\hline C & 液 & 0.101 & 0.101 & 0.058 & 0.043 & 0.042 & 0.047 & $52 \%$ \\
\hline
\end{tabular}

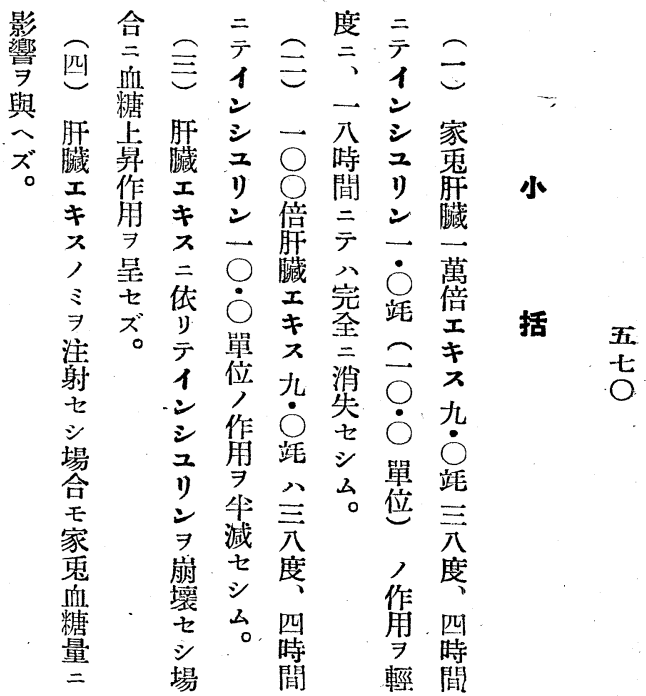



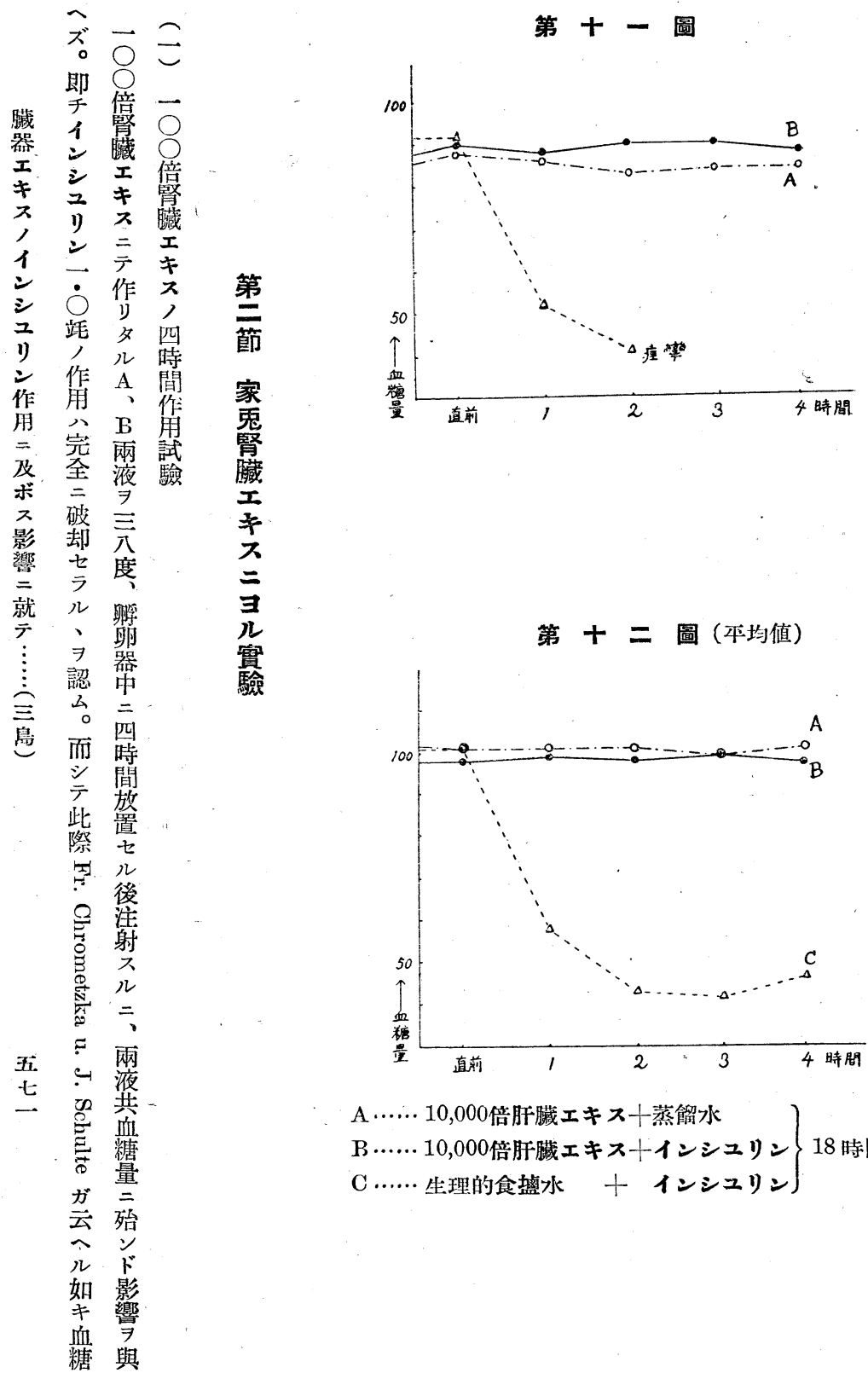
A ……10,000倍肝臟エキス十蒸餾水
B ……10,000倍肝臟エキストインシュリン 18 時間作用
$\mathrm{C}$........ 生理的食临水 
第十三表 100 倍腎臟エキス：4時間作用

\begin{tabular}{|c|c|c|c|c|c|c|c|c|c|}
\hline \multirow{3}{*}{ 月 } & \multirow{3}{*}{\multicolumn{2}{|c|}{$\begin{array}{l}\text { 注 } \\
\text { 物 質 }\end{array}$}} & \multirow{3}{*}{$\begin{array}{l}\text { 體 重 } \\
\text { (瓦) }\end{array}$} & \multicolumn{2}{|r|}{ 血 } & \multicolumn{4}{|c|}{$(\%)$} \\
\hline & & & & \multicolumn{2}{|c|}{ 注 射 前 } & \multicolumn{2}{|c|}{ 注 } & \multicolumn{2}{|c|}{ 後 } \\
\hline & & & & 30 分 & 㨁 前 & 1. 洔間 & 2 時間 & 3 時間 & 4 時間 \\
\hline $10 / \mathrm{IV}$ & A & 液 & 2300 & 0.092 & 0.092 & 0.088 & 0.088 & 0.092 & \\
\hline $17 / \mathrm{IV}$ & B & 液 & 2320 & 0.088 & 0.090 & 0.088 & 0.092 & 0.088 & \\
\hline $27 / \mathrm{IV}$ & C & 液 & 2300 & 0.092 & 0.093 & 0.061 & 0.048 & 0.045 & \\
\hline
\end{tabular}

第十四表 100 倍腎臟エキス：4時間作用 平均值

\begin{tabular}{|c|c|c|c|c|c|c|c|c|}
\hline \multirow{3}{*}{\multicolumn{2}{|c|}{$\begin{array}{l}\text { 注 入 } \\
\text { 物 質 }\end{array}$}} & & 血 & 糖 & 量 & & & \multirow{3}{*}{$\begin{array}{l}\text { 血 - 溏 量 } \\
\text { 減 少 漳 }\end{array}$} \\
\hline & & \multicolumn{2}{|c|}{ 注 射 前 } & \multicolumn{2}{|c|}{ 注 } & \multicolumn{2}{|c|}{ 後 } & \\
\hline & & 30 分 & 直 前 & 1 時間 & 2 時間 & 3 時閒 & 4 時間 & \\
\hline A & 液 & 0.094 & 0.094 & 0.092 & 0.092 & 0.094 & & $1 \%$ \\
\hline B & 液 & 0.096 & 0.094 & 0.094 & 0.090 & 0.092 & & $3 \%$ \\
\hline $\mathrm{C}$ & 液 & 0.093 & 0.092 & 0.054 & 0.047 & 0.043 & & $48 \%$ \\
\hline
\end{tabular}

インシュリン作用減衰䔞 $96 \%$

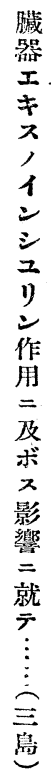

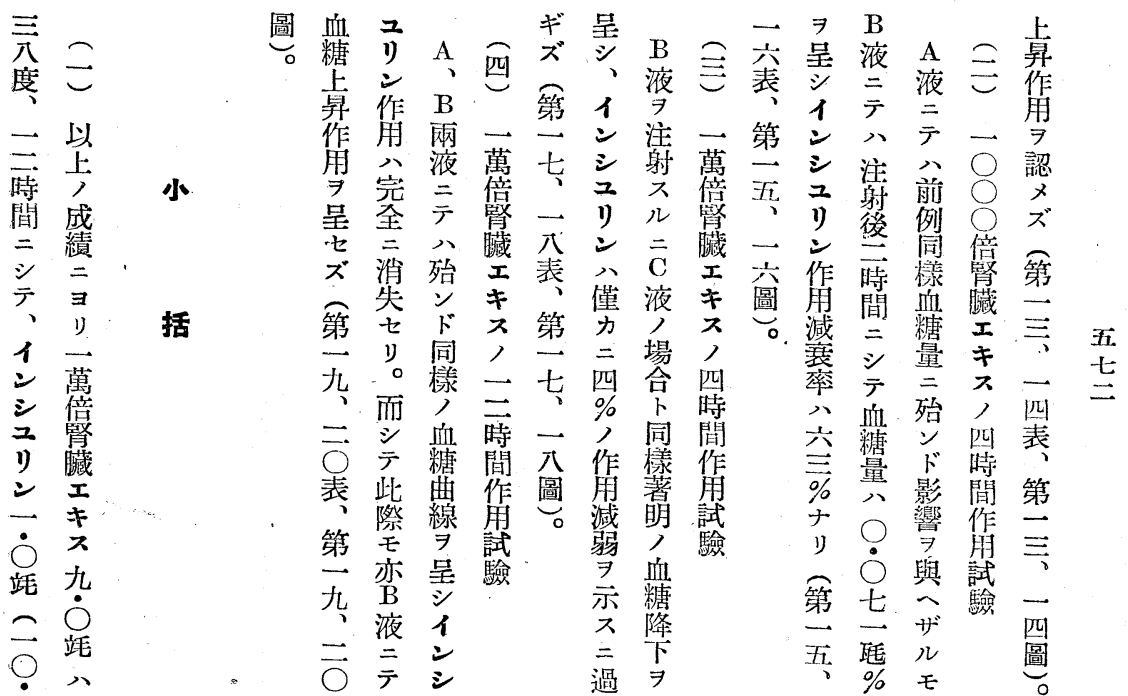




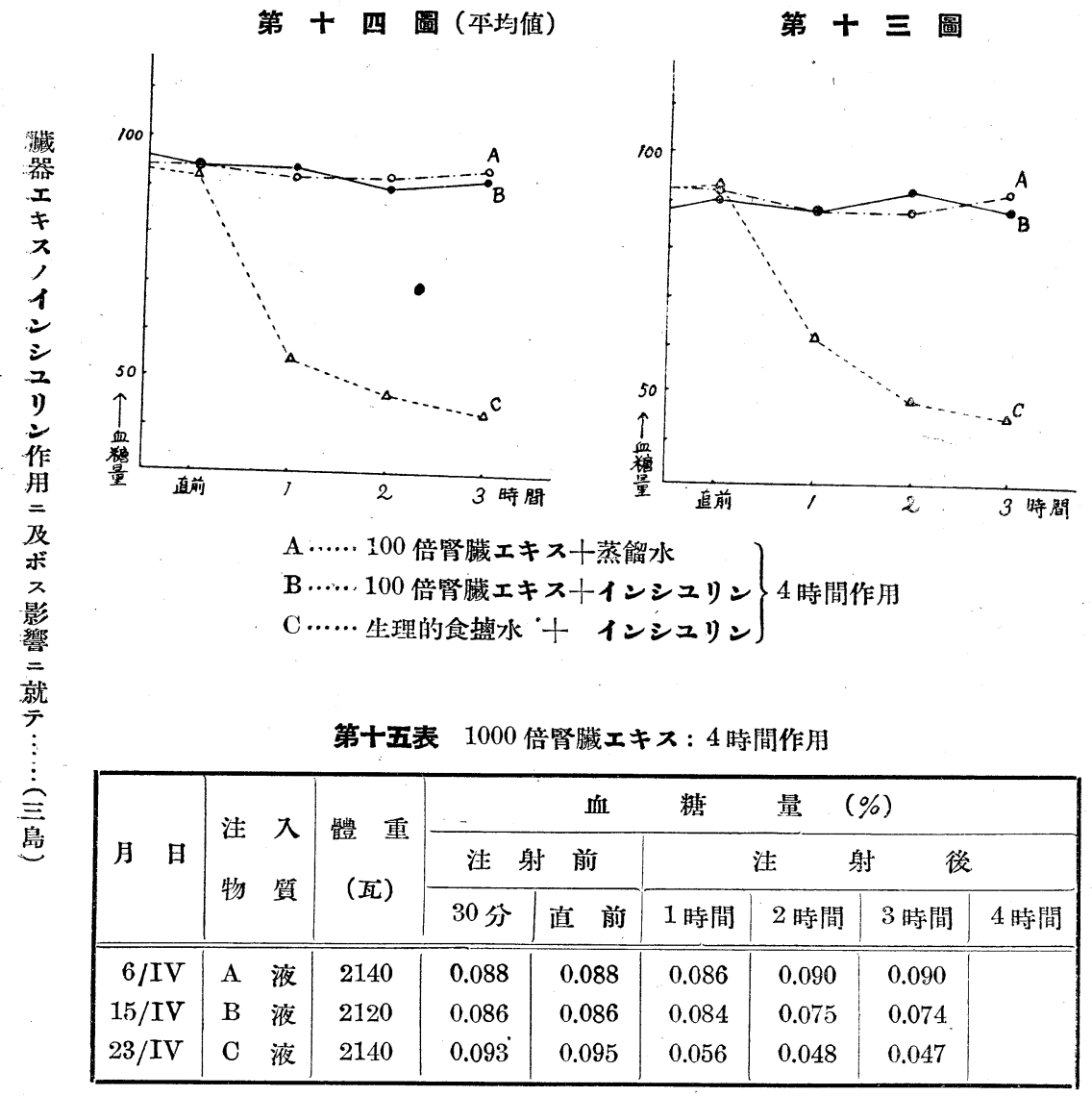

第十六表 1000 倍腎臟エキス：4 時間作用 平均值

\begin{tabular}{|c|c|c|c|c|c|c|c|}
\hline \multirow{3}{*}{$\begin{array}{l}\text { 注 } \\
\text { 物 質 }\end{array}$} & \multicolumn{2}{|r|}{ 血 } & \multicolumn{4}{|c|}{ 量 $\quad(\%)$} & \multirow{3}{*}{$\begin{array}{l}\text { 血 糖 量 } \\
\text { 減 少 率 }\end{array}$} \\
\hline & \multicolumn{2}{|c|}{ 注 射 前 } & \multicolumn{2}{|c|}{ 注 } & \multicolumn{2}{|c|}{ 後 } & \\
\hline & 30 分 & 直 前 & 1 時間 & 2 時間 & 3 時間 & 4 洔間 & \\
\hline$A$ 液 & 0.089 & 0.089 & 0.088 & 0.088 & 0.089 & & 1. $\%$ \\
\hline $\mathrm{B}$ 液 & 0.088 & 0.090 & 0.086 & 0.071 & 0.071 & & $15 \%$ \\
\hline $\mathrm{C}$ 液 & 0.091 & 0.091 & 0.053 & 0.046 & 0.045 & & $43 \%$ \\
\hline
\end{tabular}

インシュリン作用減㐮萃 $63 \%$ 


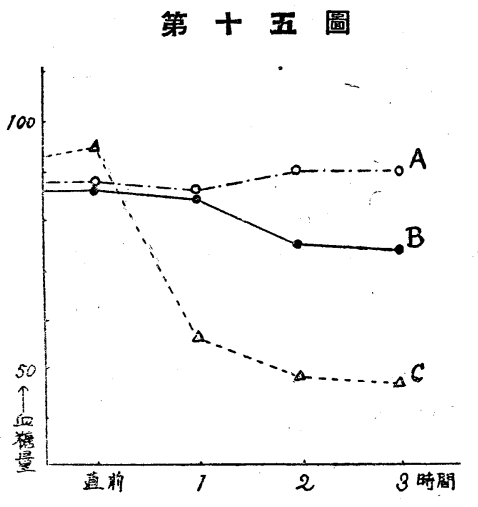

第 十 六 圖 (本均値)

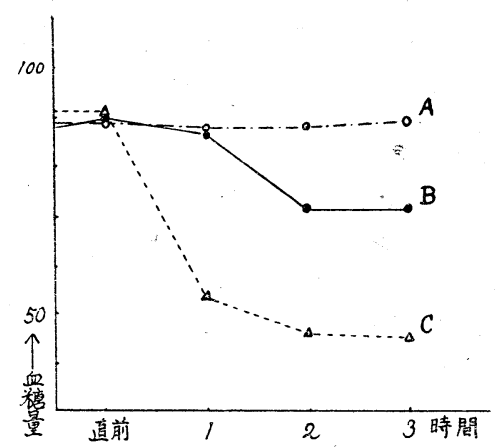

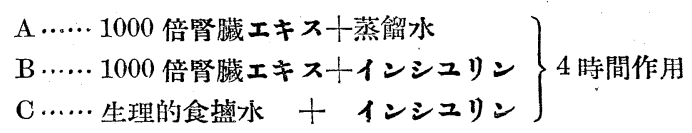

第十七表 1 萬倍腎臟エキス: 4 時間作用

\begin{tabular}{|c|c|c|c|c|c|c|c|c|c|}
\hline \multirow{3}{*}{ 月 日 } & \multirow{3}{*}{\multicolumn{2}{|c|}{$\begin{array}{ll}\text { 注 } & \text { 人 } \\
\text { 物 質 }\end{array}$}} & \multirow{3}{*}{$\begin{array}{c}\text { 體 重 } \\
\text { (瓦) }\end{array}$} & \multicolumn{2}{|r|}{ 血 } & \multicolumn{4}{|c|}{$(\%)$} \\
\hline & & & & \multicolumn{2}{|c|}{ 注 射 前 } & \multicolumn{2}{|c|}{ 注 } & \multicolumn{2}{|c|}{ 後 } \\
\hline & & & & 30 分 & 直 前 & 1 時間 & 2 時間 & 3 時間 & 4 時間 \\
\hline $4 / \mathrm{V}$ & & 液 & 2060 & 0.104 & 0.106 & 0.102 & 0.106 & 0.104 & \\
\hline $20 / \mathrm{IV}$ & & 液 & 2000 & 0.110 & 0.110 & 0.059 & 0.043 & 0.047 & \\
\hline $14 / \mathrm{V}$ & $\mathrm{C}$ & 液 & 2100 & 0.106 & 0.108 & 0.057 & 0.043 & 0.041 & \\
\hline
\end{tabular}

第十八表 1 萬倍腎臟エキス: 4 時間作用 平均値

\begin{tabular}{|c|c|c|c|c|c|c|c|c|}
\hline \multirow{3}{*}{ 注 入 } & \multicolumn{2}{|r|}{ 血 } & 糖 & 量 & & & \multirow{3}{*}{\multicolumn{2}{|c|}{$\begin{array}{l}\text { 血 糖 量 } \\
\text { 減 少 率 }\end{array}$}} \\
\hline & \multicolumn{2}{|c|}{ 注 射 前 } & \multicolumn{2}{|c|}{ 注 } & \multicolumn{2}{|c|}{ 後 } & & \\
\hline & -30 分 & 直 前 & 1 時間 & 2 時間 & 3 時間 & 4 時間 & & \\
\hline $\mathrm{A}$ 液 & 0.102 & 0.103 & 0.103 & 0.101 & 0.102 & & $1 \%$ & \\
\hline $\mathrm{B}$ 液 & 0.103 & 0.104 & 0.056 & 0.041 & 0.041 & & $56 \%$ & \\
\hline C 液 & 0.104 & 0.104 & 0.054 & 0.041 & 0.040 & & $57 \%$ & \\
\hline
\end{tabular}


第 + t圖

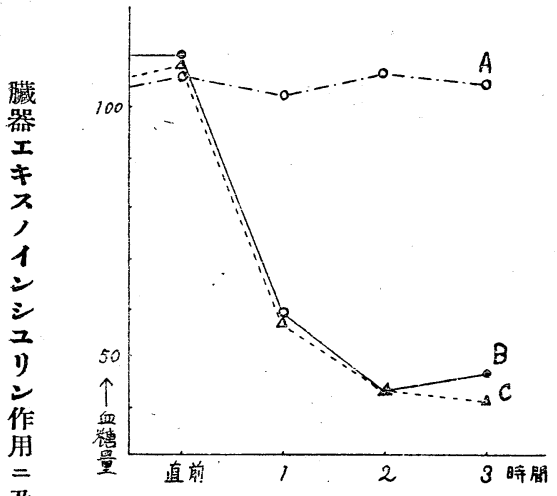

第 + 八圖 (本均值)

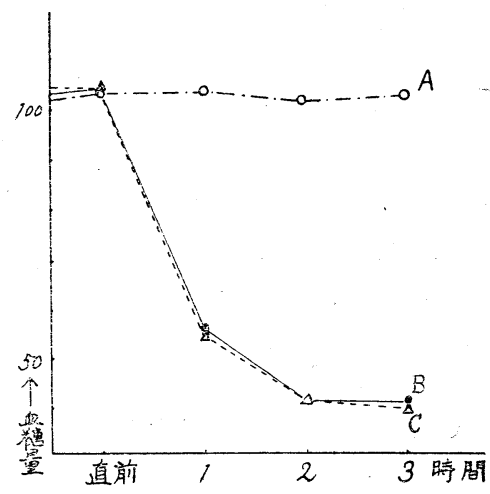
A ……10,000倍腎臟エキス十蒸餾水

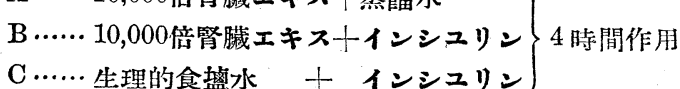

第十九表 1 萬倍腎臟エキス: 12 時間作用

\begin{tabular}{|c|c|c|c|c|c|c|c|c|}
\hline \multirow{3}{*}{ 月 日 } & \multirow{3}{*}{$\begin{array}{ll}\text { 注 } & \text { 入 } \\
\text { 物 質 }\end{array}$} & \multirow{3}{*}{$\begin{array}{c}\text { 體 重 } \\
\text { （瓦） }\end{array}$} & \multicolumn{2}{|c|}{ 血 } & 量 & \multicolumn{3}{|l|}{$(\%)$} \\
\hline & & & \multicolumn{2}{|c|}{ 注 射 前 } & \multicolumn{2}{|c|}{ 注 } & \multicolumn{2}{|c|}{ 後 } \\
\hline & & & 30 分 & 直 前 & 1 時間 & 2 洔間 & 3 時間 & 4 時間 \\
\hline $25 / \mathrm{V}$ & A 液 & 2100 & 0.095 & 0.095 & 0.097 & 0.095 & 0.093 & 0.093 \\
\hline $1 / \mathrm{VI}$ & $\mathrm{B}$ 液 & 2150 & 0.093 & 0.095 & 0.093 & 0.095 & 0.092 & 0.095 \\
\hline $10 / \mathrm{VI}$ & C 液 & 2170 & 0.099 & 0.099 & 0.061 & 0.043 & 0.038 & 0.041 \\
\hline
\end{tabular}

第二十表 1 萬倍腎臟エキス：12 時間作用 本均值

\begin{tabular}{|c|c|c|c|c|c|c|c|}
\hline \multirow{3}{*}{$\begin{array}{l}\text { 注 入 } \\
\text { 物 質 }\end{array}$} & & 血 & 糖 & 量 & & & \multirow{3}{*}{$\begin{array}{l}\text { 血 糖 量 } \\
\text { 減 少 “率 }\end{array}$} \\
\hline & \multicolumn{2}{|c|}{ 注 射 前 } & \multicolumn{2}{|c|}{ 洼 } & \multicolumn{2}{|c|}{ 後 } & \\
\hline & 30 分 & 直 前 & 1 時間 & 2 時間 & 3 時間 & 4 時間 & \\
\hline A 液 & 0.097 & 0.097 & 0.098 & 0.097 & 0.095 & 0.097 & $0 \%$ \\
\hline $\mathrm{B}$ 液 & 0.095 & 0.095 & 0.095 & 0.096 & 0.097 & 0.095 & $-1 \%$ \\
\hline $\mathrm{C}$ 液 & 0.094 & 0.094 & 0.056 & 0.046 & 0.040 & 0.044 & $50 \%$ \\
\hline
\end{tabular}




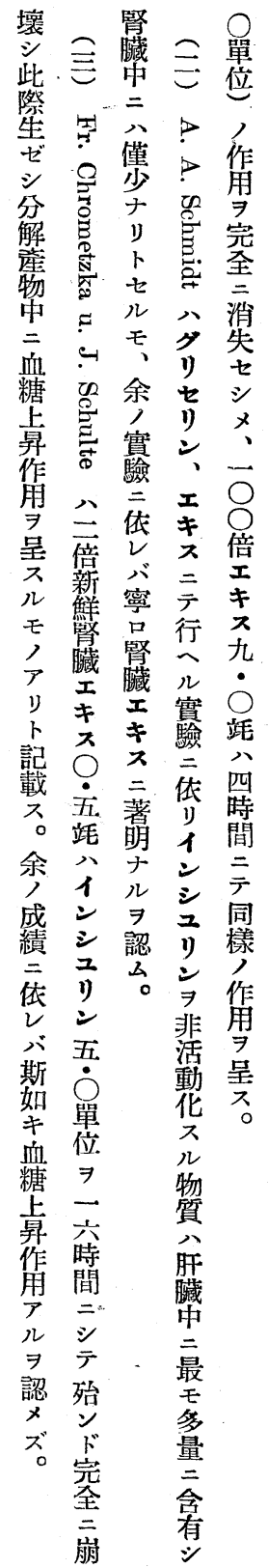

第十九 圖 (平均値)

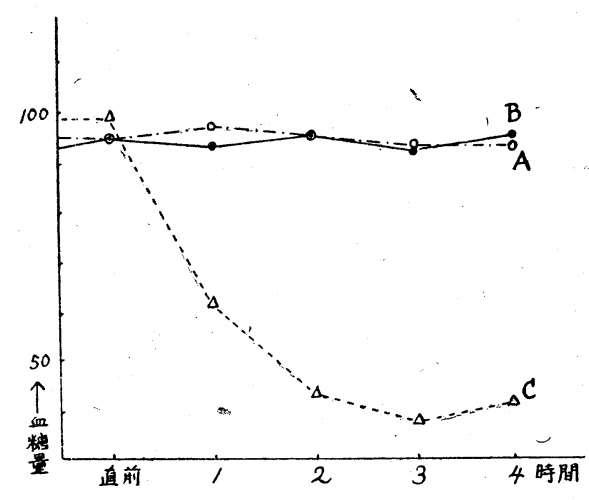

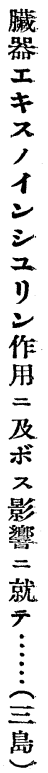

五

七

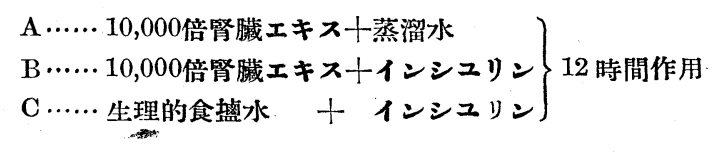




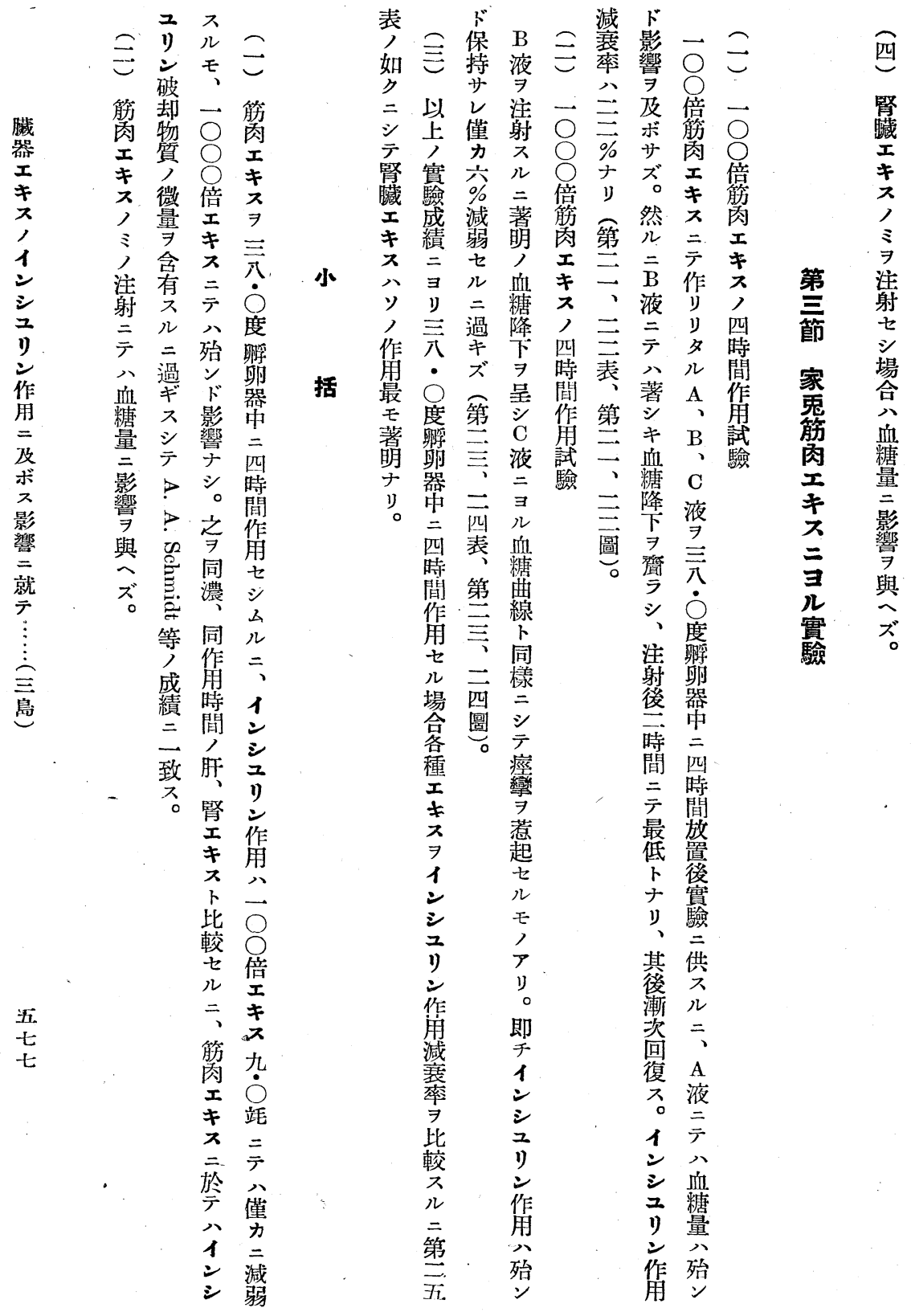


第二士一表 100 倍筋肉エキス: 4 時間作用

\begin{tabular}{|c|c|c|c|c|c|c|c|c|c|}
\hline \multirow{3}{*}{ 月 } & \multirow{3}{*}{$\begin{array}{l}\text { 注 } \\
\text { 物 }\end{array}$} & \multirow{3}{*}{ 入 } & \multirow{3}{*}{$\begin{array}{c}\text { 體 重 } \\
\text { (酉) }\end{array}$} & \multicolumn{2}{|r|}{ 血 } & 糖 & \multicolumn{3}{|c|}{$(\%)$} \\
\hline & & & & \multicolumn{2}{|c|}{ 注 射 前 } & \multicolumn{2}{|c|}{ 注 } & \multicolumn{2}{|c|}{ 後 } \\
\hline & & & & 30 分 & 㨁 前 & 1 時閒 & 2 時間 & 3 時間 & 4 時間 \\
\hline $21 /$ IV & A & 液 & 1900 & 0.108 & 0.100 & 0.106 & 0.106 & 0.108 & \\
\hline $8 / \mathrm{IV}$ & B & 液 & 1840 & 0.110 & 0.111 & 0.066 & 0.056 & 0.068 & \\
\hline $30 / \mathrm{IV}$ & C & 液 & 1920 & 0.108 & 0.106 & 0.065 & 6.048 & 0.047 & \\
\hline
\end{tabular}

第二十二表 100 倍筋肉エキス: 4 時間作用 本均值

\begin{tabular}{|c|c|c|c|c|c|c|c|c|c|}
\hline \multirow{3}{*}{\multicolumn{2}{|c|}{$\begin{array}{l}\text { 注 } \\
\text { 物 }\end{array}$}} & & 血 & 糖 & 量 & & & \multirow{3}{*}{\multicolumn{2}{|c|}{$\begin{array}{l}\text { 血 糖 量 } \\
\text { 減 少率 }\end{array}$}} \\
\hline & & \multicolumn{2}{|c|}{ 洼，射 前 } & \multicolumn{2}{|c|}{ 注 } & \multicolumn{2}{|c|}{ 後 } & & \\
\hline & & 30 分 & 直 前 & 1 時間 & 2 時間 & 3 時間 & 4 時間 & & \\
\hline $\mathbf{A}$ & 液 & 0.104 & 0.105 & 0.105 & 0.103 & 0.104 & & $1 \%$ & \\
\hline B & 液 & 0.106 & 0.106 & 0.060 & 0.054 & 0.064 & & $44 \%$ & \\
\hline $\mathrm{C}$ & 液 & 0.101 & 0.102 & 0.057 & 0.045 & 0.042 & & $55 \%$ & \\
\hline
\end{tabular}

インシュリン作用減衰筿 $22 \%$

第 $=+$ - 圖

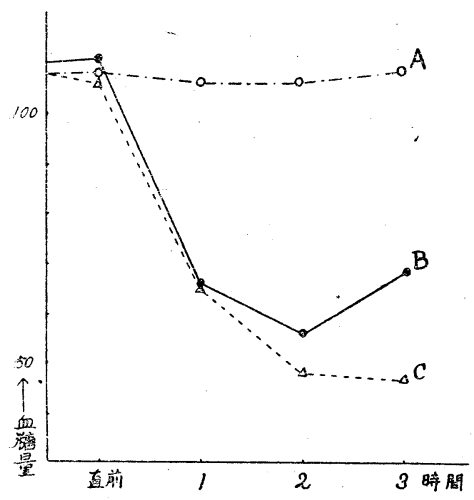

管 $=+$ 二 圖 (平均値)

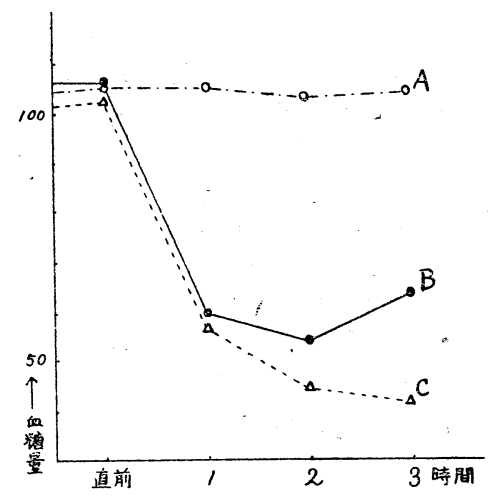

五.

公

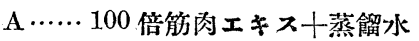

$\mathrm{B} \cdots \cdots \cdot 100$ 倍筋肉エキストインシュリン 44 時間作用

$\mathrm{C}$ ……生理的食㙏水 十 インシュリン 
第二十三表 1000 倍筋肉エキス: 4 時間作用

\begin{tabular}{|c|c|c|c|c|c|c|c|c|c|}
\hline \multirow{3}{*}{ 月 日 } & \multirow{3}{*}{$\begin{array}{l}\text { 注 } \\
\text { 物 }\end{array}$} & \multirow{3}{*}{$\begin{array}{l}\text { 入 } \\
\text { 質 }\end{array}$} & \multirow{3}{*}{$\begin{array}{c}\text { 體 重 } \\
\text { (瓦) }\end{array}$} & \multicolumn{2}{|r|}{ 血 } & \multicolumn{4}{|c|}{$(\%)$} \\
\hline & & & & \multicolumn{2}{|c|}{ 注 射 前 } & \multicolumn{2}{|c|}{ 注 } & 寸 & \\
\hline & & & & 30 分 & 直 前 & 1 時間 & 2 時間 & 3 時間 & 4 時間 \\
\hline $13 / \mathrm{VI}$ & A & 液 & 2420 & 0.095 & 0.097 & 0.097 & 0.099 & 0.095 & \\
\hline $1 / \mathrm{VI}$ & B & 液 & 2400 & 0.099 & 0.097 & 0.057 & 0.047 & 0.041 & \\
\hline $26 / \mathrm{VI}$ & C & 液 & 2400 & 0.093 & 0.092 & 0.059 & 0.045 & 0.043 & \\
\hline
\end{tabular}

)

花

第二十四表 1000 倍筋肉エキス: 4 時間作用 本均值

\begin{tabular}{|c|c|c|c|c|c|c|c|}
\hline & & 血 & 椃 & 量 & & & \multirow{3}{*}{$\begin{array}{l}\text { 血 溏 量 } \\
\text { 減 少率 }\end{array}$} \\
\hline & \multicolumn{2}{|c|}{ 注 射 前 } & \multicolumn{2}{|c|}{ 注 } & \multicolumn{2}{|c|}{ 後 } & \\
\hline & 30 分 & 直 前 & 1 時間 & 2 時間 & 3 時間 & 4 時間 & \\
\hline A 液 & 0.095 & 0.095 & 0.094 & 0.094 & 0.095 & & $1 \%$ \\
\hline $\mathrm{B}$ 液 & 0.094 & 0.093 & 0.053 & 0.041 & 0.041 & & $52 \%$ \\
\hline $\mathrm{C}$ 液 & 0.098 & 0.097 & 0.052 & 0.042 & 0.041 & & $54 \%$ \\
\hline
\end{tabular}

島

インシンリン作用減衰率 $6 \%$

第 $=+$ 三圖

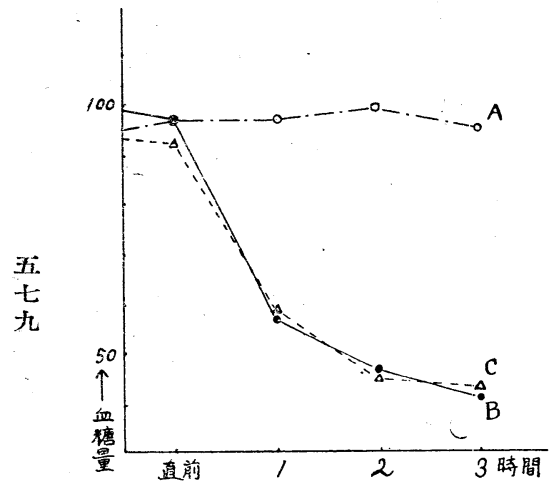

第 二十四 圖 (平圴值)

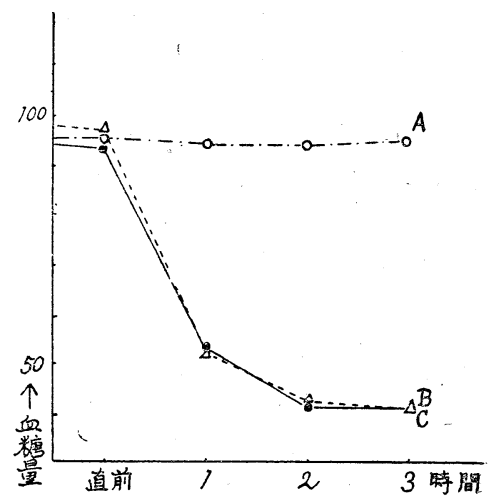
A ……1000 倍筋肉エキス十蒸餾水
B ……1000 倍筋肉エキストインシュリン
$\mathrm{C}$ ……生理的食㧫水 + インシュリン 
第二十五表 $38^{\circ} \mathrm{C}, 4$ 時間作用時二於々ルインシュリン作用 隇衰率卜藏器エキスノ濃度トノ關保

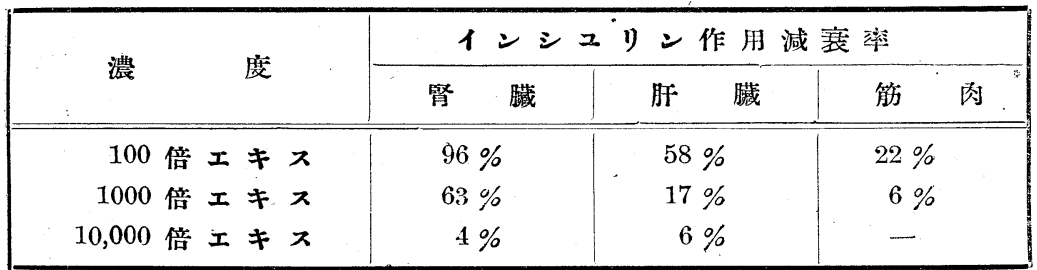

西

ב モ

作

工竓

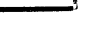

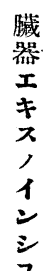

注 四

成 三

り 多 V 績 八 = 用

用 三

リ八气及家

身

ス 1 筋, 腎 含 $\exists$ 完 -

ル

ル $ン$

肉

藏 有

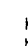

.

$\rightarrow$

异 手

, $=$

云 其

人 作

儿用

ガ

如完

キ 全

血 =

糖 渻

上 失

景 七

作 シ

用

認 後

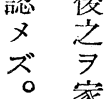

致

平

エ シ 減

全

‥

八

腎

ス 堅 シ 却臟

$=$ =臟 ム

テテ中 中

工

立

荃犝 度 シ 響 臟

○ 1 影肝

들 精 藏

○三 リ 檢 並

两時 八 ル 筋

八最二過モ、元單間腎二肉

モモハ代

シ 萻 少 ズ

ン 明量。

- $\dot{0}$

$\bigcirc$ 证

リ崩在

O 谁

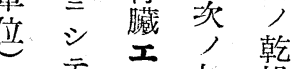




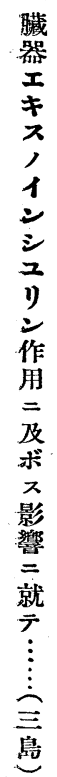

Ш્0

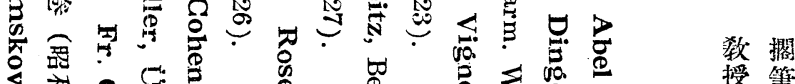

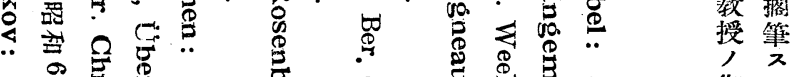

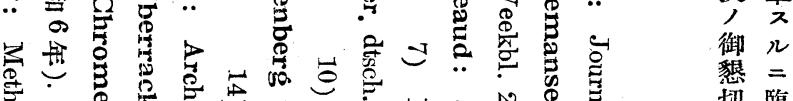

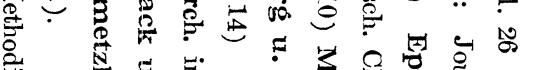
( 切 臨

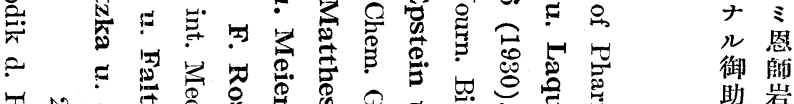
四怘

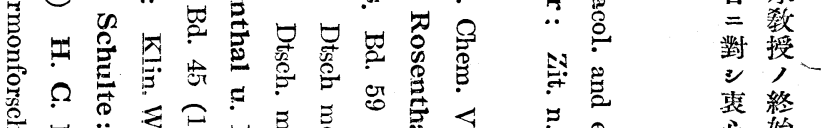

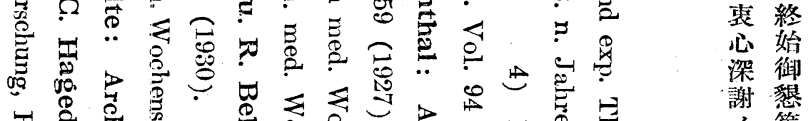

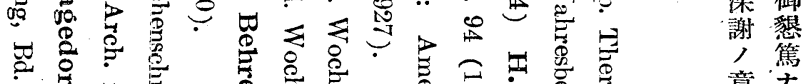

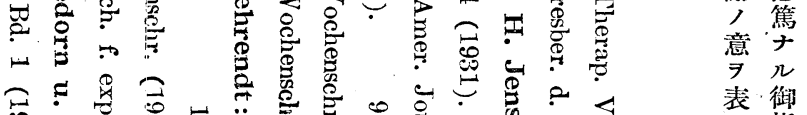

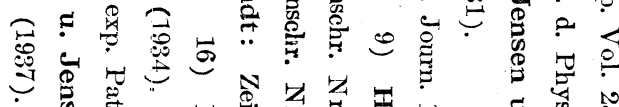

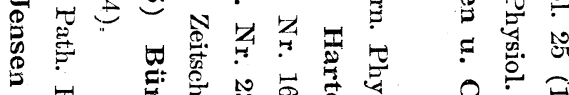

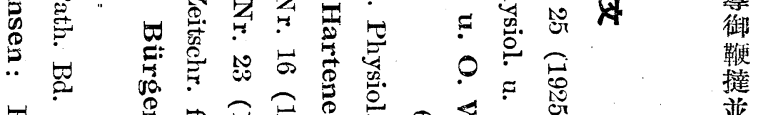

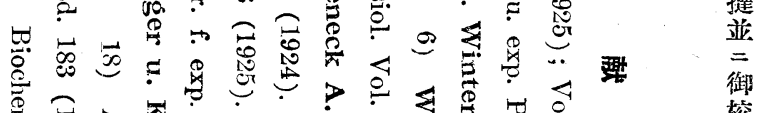

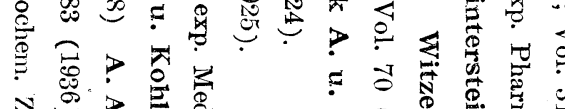
ㄱ.

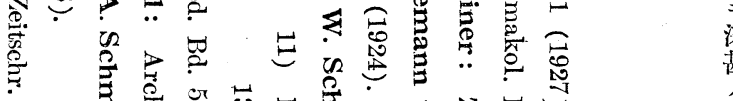
ए 元

五. 它脰产.

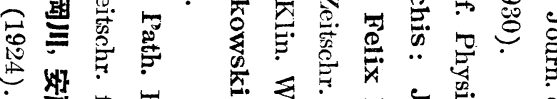

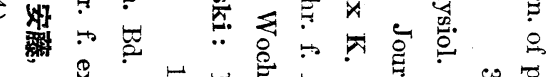

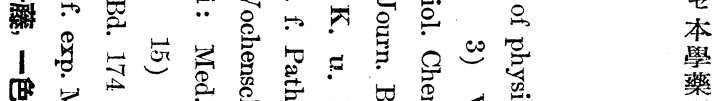

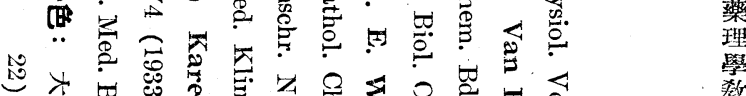

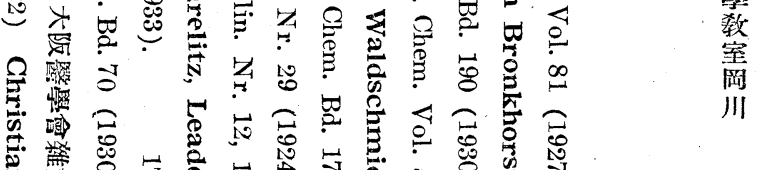


nur ein einheitlichen Ursache zu erklären.

2) Wie Hashimoto schon vorschlagt hat, scheint es mehr gerechtfertigt zu sein diese in folgenderweise zu einteilen.

1. Die Faktoren, die in mechanischen Schädlichkeiten bestehen.

2. Die Faktoren, die in thyreotoxischen Schädlichkeiten bestehen.

3. Die Faktoren, die in oben geführten beiden Schädlichkeiten bestehen.

4. Die Faktoren, die mit der anderen organischen Veränderungen des Herzens zusammenschlussen.

3) - Bei der endemischen Struma ist er häufig auf die mechanischen Schädlichkeiten zurückführen zu sein.

4) Denkbar ist aber auch, dass bei der grossen Struma die übermässige Blutversorgung vaskulöser Kröpfe eine Ueberlastung für das Herzen geben.

5) Ich glaube wohl, dass die Strumektomie einen guten Erfolg die Störungen des Herzens zu wiederherstteren, entfernd die mechanische und toxische Schädlichkeit, bringt.

(Autoreferat).

\title{
Einfluss der Organextrakte auf die Insulinwirkung.
}

\author{
Von
}

Dr. D. Mishima.

Aus der Chirurgischen Klinik der Kaiserl. Universitat zu Ôsaka. (Vorstand Prof. Iwanaga.)

Der Verfasser hat untersucht den Einfluss der Organextrakte, nämlich aus der Leber, der Niore und den Muskeln, auf die Insulinwirkung. Die Organextrakte aus obenerwähnten Organen wurden aus den getrockneten und dann pueversierten Organen mittels physiologischer Kochsalzlösung, deren $\mathrm{pH}$ auf 7,0 eingestellt ist, 
gewonnen. Die Arbeitsergebnisse zeigen folgendes :

1) Die Insulinwirkung wird am stärksten durch den Nierenextrakt aufgehoben. 9,0 ec des auf 110000 verdünnten Nierenextraktes (gewichtsmässig verdünnt) vermag bei 12 stündiger Einwirkung bei $38^{\circ} \mathrm{C}$ und dieselbe Menge des auf $1: 100$ verdünnten Nierenextraktes vermag bei nur 4 stündiger Einwirkung bei $38^{\circ} \mathrm{C}$ völlig die Wirung von 1,0 ce (10.0 E.H.) Insulin zu unterbinden.

2) 9,0 ec des auf $1: 10000$ verdünnten Leberextraktes vermag bei 18 stündiger Einwirkung bei $38^{\circ} \mathrm{C}$ völlig die Wirkung von 1,0 cc Insulin zum Schwinden zu bringen, aber dieselbe Menge des auf $1: 100$ verdünnten Leberextraktes kann bei 4 stündiger Einwirkung bei $38^{\circ} \mathrm{C}$ die Insulinwirkung nur auf die Hälfte herabsetzen. Nach A. A. Schmidt soll die insulinzerstörende Substanz am meisten in der Leber und nur in kleiner Menge in der Niere vorhanden sein. Dementgegen stellte der Verfasser das stärkene Vorkommen diesersubstanz in Nierenevtrakte fest; in dem Leberextrakte dagegen war diese Substanz zwar nachweisbar, aber in kleinerer Menge vorhanden als im Nierenextrakt.

3) Der Mnskelextrakt schwächt die Insulinwirkung nur leicht, welches Ergebnis mit dem von A. A. Schmidt übereinstimmt.

4) Behandelt man. Insulin mit Leber- oder Nierenextrakt, bis die eigentliche Insulinwirkung verschwindet, und injiziert dann dieses vorbehandelte Insulin dem Kaninchen, so tritt beim Versuchstiere keine Hyperglykämie anf, welches Ergebnis dem von Fr. Chrometzka und J. Schulte völlig entgegengesezzt ist.

(Autoreferat) 